\title{
The Efficiency of Water in Supporting Local Wisdom and Food Sustainability in Subak Sange, Bali Indonesia
}

\section{Ni Made Delly Resiani and I Wayan Sunanjaya}

Assessment Institute for Agricultural Technology (IAARD) Bali, By Pass Ngurah Rai, Pesanggaran, Denpasar, Indonesia 80222

\section{ARTICLE INFO}

\section{Received}

30 October 2019

\section{Revised}

12 April 2020

\section{Accepted for Publication \\ 2 June 2020}

\section{Published}

5 August 2020

doi: 10.29244/j.agromet.34.2.67-74

\section{Correspondence:}

Ni Made Delly Resiani

Assessment Institute for Agricultural

Technology (IAARD) Bali, By Pass

Ngurah Rai, Pesanggaran, Denpasar, Indonesia 80222.

Email: dellyresiani67@gmail.com

This is an open-access article distributed under the CC BY License. (c) 2020 The Authors. Agromet.

\begin{abstract}
A B S T R ACT
Subak is local wisdom in Bali that has been practiced for centuries in managing irrigation water. Here we present the uniqueness of Subak to manage water with an example of Subak Sange, Gianyar, Bali. The field activity was carried out from April-September 2019. The research objectives were to analyze: (i) the characteristics of local wisdom in Subak Sange, (ii) the effect of irrigation water frequency on pest and disease outbreaks on tobacco yield, and (iii) the efficiency of water use in chili-tobacco intercropping. We combined several approaches to achieve the objectives, including an interview with farmer, diversity analysis, Romijn method, and revenue cost ratio. The results showed that the harmony of relations between farmers was bound by a belief in three elements socio-agrarian-religious. The excessive irrigation gave more pest and disease outbreaks, as shown in 6-irrigation frequencies. In addition, the occurrence of rotten root outbreaks was the highest (29\%). The optimal frequency irrigation for yield of tobacco was 4-times, which produced 11.5 tons of dry chopped tobacco per hectare, and this frequency irrigation was much more efficient water use by $79 \%$ than rice plants. Based on revenue cost ratio analysis, the chili-tobacco intercropping with four times irrigation was feasible. The findings indicate that management of irrigation water in Subak Sange is promising to support food sustainability in the region.
\end{abstract}

\section{KEYWORDS}

chili-tobacco intercropping, dry chopped-tobacco, irrigation frequency, revenue cost ratio, tobacco disease

\section{INTRODUCTION}

In Indonesia, agriculture is one of the crucial sectors in national development. The government has made various efforts to increase the production of agricultural commodities. However, earlier study suggested that farmers were more prefer to do agriculture practices based on their own experiences rather than introducing more advanced agricultural technology instead (Sulaiman et al., 2018). These practices are related to the low knowledge and technical skill that farmers have. Other factors, such as limited capital and socio-cultural aspects, also contribute to the use of more advanced agricultural technology. Most farmers still hold the believed tradition tightly to manage agriculture. This pheno- menon is commonly found in Bali farmers, especially when they manage irrigation water. Their agriculture practices to manage and regulate irrigation water are known as Subak system. Nowadays, Subak is the most effective farmer associations in controlling irrigation water and remarked as a socioreligious pattern based on Tri Hita Karana (Norken et al., 2017; Wijayanti et al., 2020; Yekti et al., 2017).

The essential practices at the Subak association are mutual understanding, feeling, and having togetherness based on deep conviction as the basis of local wisdom of agriculture in Bali. Local wisdom is indigenous ideas that are wise, useful and followed by community members. In general, local wisdom values appear and develop through repeated experiences and learnings that are wisely addressed. Then, local wisdom 
evolves into a belief, trust, and mutual agreement (Sulaiman et al., 2018; Yekti et al., 2017). In changing climate, plant species and cropping systems may influence water use efficiency under the Subak system. This study will portray climate adaptation on Subak Sange in Gianyar, Bali related to water management and plant species selection.

In changing climate, likely there is a tendency a decreased water availability in the future, while water demand continues to increase, especially in urban areas (Flörke et al. 2018). An increased water demand is affected by population growth and human activity. In the long run, an increased demand potentially leads to a water conflict (Ashofteh Parisa-Sadat et al., 2017; Luo et al., 2015; Petersen-Perlman et al., 2017; Wu et al., 2016). Water resources may associate with environmental problems leading to conflicts when the resources are limited (Boulay et al., 2018; Tarigan et al., 2016). Therefore, water has become an essential natural resource for all living creatures. Specifically, in agriculture, water is one of the essential matters which has a strategic function in agricultural land, especially on paddy fields as the primary basis of national food security.

In the agronomic context, water is an essential component for plant growth and development (Seidel et al., 2017; Yusara et al., 2019), as some types of plants require large amounts of water (Lambers and Oliveira, 2019). The water content in the fresh weight of cells and plant tissue reaches more than $80 \%$ of total weight. Water functions for plants, among others, can be used as nutrient solvents, constituents of protoplasm, and raw material for photosynthesis. Lack of water in plant tissue can decrease cell turgor, increase macromolecular concentrations, and affect the cell membrane and chemical activity of water in plants (Wulandari et al., 2018). On the other hand, an adequate water will increase agricultural productivity and food security (Kang et al., 2017; Quist-Jensen et al., 2015). To support optimal growth, plants require adequate nutrients and water throughout their span life. Nutrients in soil are mainly obtained from fertilization (Putra and Yuliando, 2015), while irrigation water like Subak system will fulfill plant water requirements.

Rapid growth and an increased crop yields can be achieved with proper irrigation (Parent et al., 2015). The provision of water can be intended to replace water that has been evaporated and provide additional water needed by plants (Abdolahipour et al., 2018). Water shortage over specific periods may lead plants to wither, as there is not enough water to compensate water loss through evapotranspiration. Prolonged insufficient water will trigger plants to become stunting and abnormal (Ilangumaran and Smith, 2017).
The problem of water shortages also occurs in agricultural practices using the Subak method in Gianyar, Bali. In the Subak Sange, the farmers usually plant chili-tobacco and rice intercropping. Practically, they also have a similar problem with water shortage during their agricultural practices. Therefore, proper identification on this issue is needed to find effective and efficient solutions related to the water shortage problem.

The culture of intimate solidarity among Subak farmers is tight in the management of agricultural water. This culture is very unique, therefore many efforts have been performed to reveal on this (e.g., Jansing et al., 2020; Tarigan et al., 2016; Yekti et al., 2017). This research will focus on Subak Sange, with the specific objective to identify: (i) local wisdom of Subak Sange, (ii) the effect of irrigation water frequency on pests and diseases outbreaks and tobacco yields, (iii) irrigation efficiency on rice plants with chili-tobacco intercropping, and (iv) the feasibility analysis of tobacco farming in supporting food sustainability in irrigated farmlands.

\section{RESEARCH METHODS}

A field experiment was carried out in Subak Sange, Ketewel Village, Sukawati District, Gianyar Regency, Bali Province. The experiment was done from April to September 2019.

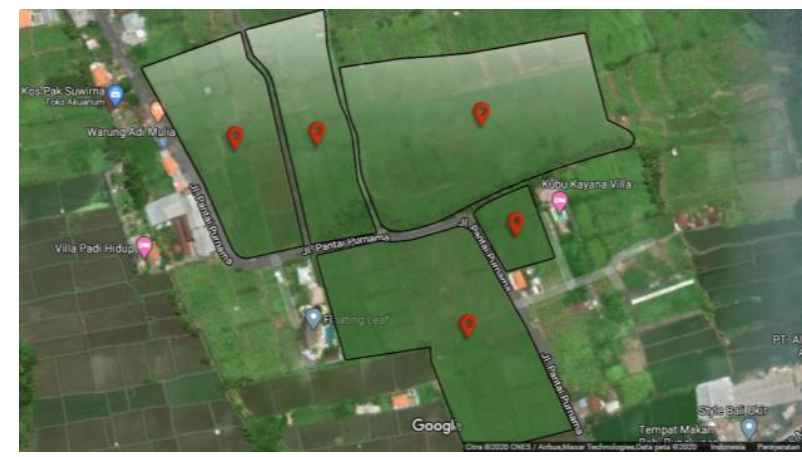

Figure 1. The location of the study area

During the field activities, we did interviews and limited discussions with community leaders to identify local wisdom in Subak Sange. In addition, we established research demonstration plots in the field. The demonstration plots were used to obtain information about the effect of the frequency of irrigation water on pests, diseases, and tobacco yield (Figure 1). We also observed data related to the irrigation water efficiency under rice plants and chilitobacco intercropping from the demonstration plots.

We designed the plots following a randomized block design. There were four treatments for the frequency of irrigation water in chili-tobacco and rice 
intercropping. The four treatments included: (i) $A 1=3$ times (day 0, 45, and 90 after planting); (ii) $\mathrm{A} 2=4$ times (day 0, 30, 60, and 90); (iii) A3 = 5 times (day 0, 45, 60, 75, and 90); and (iv) A4 = 6 times (day 0, 25, 40, 55, 70, and 85). Each treatment was replicated seven times. The cultivation of the chili-tobacco intercropping system was implemented together with rice planting on a Subak landscape. Planting was performed by dividing the landscape into two areas. The first area was for chilitobacco intercropping, and the second one was for rice plants. This planting condition was carried out within a year; then, it was rotated.

The cultivation of chili-tobacco was started by seed sowing, then clean-up the land with cutting rice paddy. Then we continued with establishing beds with a size of $100 \mathrm{~cm}$ width, $70 \mathrm{~cm}$ height, and spacing between beds was $90 \mathrm{~cm}$. The spacing of tobaccos was $90 \times 90 \mathrm{~cm}$, and we cultivated chili between them as intercropped plants. The day before planting ( 0 days before planting), watering is done by a lab system to ease the cultivation process. The lab system is an irrigation technique by flowing water into a plot of land until the water reaches the surface of the mound, then the incoming water is closed. The irrigation water was adjusted according to the four treatments.

Rice planting was carried out by following procedures of Integrated Rice Cultivation Management (Badan Litbang Pertanian, 2007), which include: (i) cultivation the new high yielding seed varieties, (ii) use the 2:1 Legowo planting method (Tapin) with ticks $25 \times 25 \mathrm{~cm}$, (iii) organic and inorganic fertilization where the dose of organic fertilizer is at least 2 tons ha ${ }^{-1}$, (iv) plant the young seedlings $<21$ days with 1-3 seedlings in one hole, (v) seeding is not too tight, (vi) intermittent irrigation using a control pipe, (vii) integrated pest control, and (viii) harvesting follows harvest criteria.

Measurement of irrigation water use for both intercropping chili-tobacco and rice followed the requirements of the Romijn method. Technically, Romijn device was installed on the distribution channel of incoming water (copper). Water entering the rice field was through this gauge.

In the field, we observed the following parameters: (i) Subak local wisdom, (ii) water use in rice and chili-tobacco fields, (iii) intensity of caterpillar attacks, leafhoppers, aphids, rotten roots, and tobacco leaf curl viruses, (iv) revenue of dry cut tobacco, and (v) farming analysis of tobacco (revenue cost ratio). The farming analysis was calculated based on the calculation of revenue cost ratio $(R C R)$, using data of income and expense to do farming. The RCR value $>1$ means that farming is profitable or feasible to be executed-the $R C R$ value $<1$ means that farming suffers losses and is not possible to be executed. Furthermore, the RCR value $=1$ indicates that it is at the breakeven point. $R C R$ values can be analyzed using Equation (1) (Asnidar and Asrida, 2017):

$$
\mathrm{RCR}=\frac{\text { Total income (IDR) }}{\text { Total cost production (IDR) }}
$$

\section{Data Analysis}

Data of local wisdom, which were obtained from interviews and discussions, were presented descripttively. For the quantitative data such as pest and disease outbreaks were analyzed using variance analysis and BNT test $(\alpha=5 \%)$. The BNT test is commonly used to see the effect of treatment on significant differences among observed parameters (Gomez and Gomez, 1995).

The discharge in cross-sections entering the paddy field was calculated based on the Romijn method. The Romijn method is shown in Equations (2) and (3) (Andayani et al., 2017):

$$
\begin{aligned}
& Q=m b \frac{2}{3} \sqrt{2 g \frac{1}{3} h} \\
& Q=1.71 m b h^{3 / 2}
\end{aligned}
$$

where $\mathrm{Q}$ is the discharge $\left(\mathrm{m}^{3} \mathrm{~s}^{-1}\right), \mathrm{b}$ is the door width $(\mathrm{m}), \mathrm{h}$ is the height of the water above the threshold $(\mathrm{m}), \mathrm{g}$ is the acceleration due to gravity $\left(9.8 \mathrm{~m} \mathrm{~s}^{-1}\right)$, and $m$ is the flow coefficient.

The drainage coefficient in Equation (2) and (3) has a value $<1$. If channel length $(L)$ is three times higher than the water level at the gate, the flow coefficient value ranges from 0.970 to 0.980 . If the length $(L)$ is the same as the water level, the flow coefficient value ranges from 0.98-1.01.

\section{RESULTS AND DISCUSSIONS}

\section{Local Wisdom of Subak and Regional Characteristics}

Subak is the local wisdom of the Balinese society in managing water resources and water use for agriculture. Subak culture was bound by psychological strength/firm beliefs of the three essential elements, namely socio-agrarian-religious. These three elements are based on the philosophy of Tri Hita Karana. The culture as a belief system cannot stand alone, which depends on the harmonized relationship among farmers, environment, and God. In general, the utilization of irrigation water by Subak based on equity and fairness with a system called "tektek". This system distributes irrigation water based on an area per 100 acres, which was determined by "juru air".

Based on the interview with Pekaseh, Subak's chief who controls irrigation water in Subak system, in 2019, farmers still have applied continuous irrigation 
water management that was practiced as an ancestral heritage. This irrigation is typically for cropping patterns of rice-rice-rice for the entire Subak region. Due to climate variability, the water supply for irrigation was decreased. Therefore, the decreased water supply affected the sustainability of irrigation, leading to an abnormal cropping pattern. Farmers experienced with various difficulties related to water problems. This problem has directed Subak members to adapt to the cropping pattern. They discussed about the water management and type of crops that could be planted. Based on the discussion, they decided to divide the Subak area into two cropping patterns. Half of the area was planted with a rice-rice-rice system (ancestral heritage), and the rest for the chili-tobacco intercropping system. Another agreement was to distribute the irrigation water every five days for chili-tobacco intercropping, and they did not mind with the sufficiency of water in a different area.

Subak Sange is located in Ketewel Village, Gianyar Regency, Bali Province. The area of Subak Sange is around 43 ha divided into two areas, namely Tempek Gliud and Tempek Papadan. Tempek Gliud was advised to grow the chili-tobacco intercropping system, while the latter for rice only. This division was for a year only; then the next year crop rotation applied for both.

The soil in Subak Sange is typically sandy loam texture, which is suitable for agriculture, both rice and chili-tobacco plants (BPP Sukawati, 2015). During the dry season, Subak Sange farmers rely on the information about rainfall (Figure 2). The average monthly rainfall over the past seven years in Subak Sange was shown in Figure 2. The dry period occurs in April-October with total rainfall $<120 \mathrm{~mm} /$ month.

\section{Effect of Irrigation Water Frequency on Pest and Disease Outbreaks and Tobacco Dry Yields}

Based on the statistical analysis, the irrigation water frequency on chili-tobacco intercropping system gave a significant effect on the pest and disease outbreaks $(\alpha=5 \%)$, as well as the yield of dry chopped tobacco leaves (Tables 1 and 2). Table 1 shows that the percentage of caterpillar outbreaks, rotten roots, and tobacco leafhopper outbreaks were significantly different in various treatments. The highest outbreak of tobacco leaf caterpillars was shown in the treatment of A4 (2.74\%), followed by A2 and A3 (2.36\% and 2.32\%), whereas the lowest outbreak was in treatment $A 1$ (2.22\%). A similar phenomenon was found in A4 treatment, where the rotten roots outbreak was the highest $(28.71 \%)$, then followed by A3 (15.71\%). The lower outbreak rates of the rotten roots were found in $A 1$ and $A 2$ treatments ( $<13 \%$, Table 1$)$. For leafhopper outbreaks, A1 treatment had the highest outbreak (24.87\%), while A4 treatment had the lowest outbreak (16.40\%). Other treatments $A 2$ and $A 3$ had the outbreaks of $18.05 \%$ and $22.94 \%$, respectively.

Table 2 shows the significant effect of irrigation water frequency on outbreaks of aphid and tobacco leaf curl viruses, and dry chopped tobacco leaf yields. The highest aphid outbreaks were shown in A4 treatment $(13.65 \%)$, then followed by treatment $\mathrm{A} 2$ (12.04\%), A1 (11.91\%), and the lowest at A3 (11.31\%). Tobacco leaf curl viruses had the highest outbreak at A4 treatment (14.18\%), followed by A3 (11.59\%). A2 and $\mathrm{A} 1$ treatments were only had outbreaks by less than $11 \%$ each.

The treatment of irrigation water also influenced the yield of dry chopped tobacco leaves. In A1 treatment with three times irrigation water, the yield of dry chopped tobacco leaves was $11,181 \mathrm{~kg} \mathrm{ha}^{-1}$. With an increased irrigation water (6 times), the weight of dry chopped tobacco leaves decreased by $25 \%(8,364 \mathrm{~kg}$ $\mathrm{ha}^{-1}$ ). Five times irrigation water (A3) resulted in 9,591 $\mathrm{kg} \mathrm{ha}^{-1}$ of dry leaves. The result showed that four times irrigation water (A2) was the optimal treatment with the dry chopped tobacco leaves was the highest (11.5 ton $\mathrm{ha}^{-1}$ ).

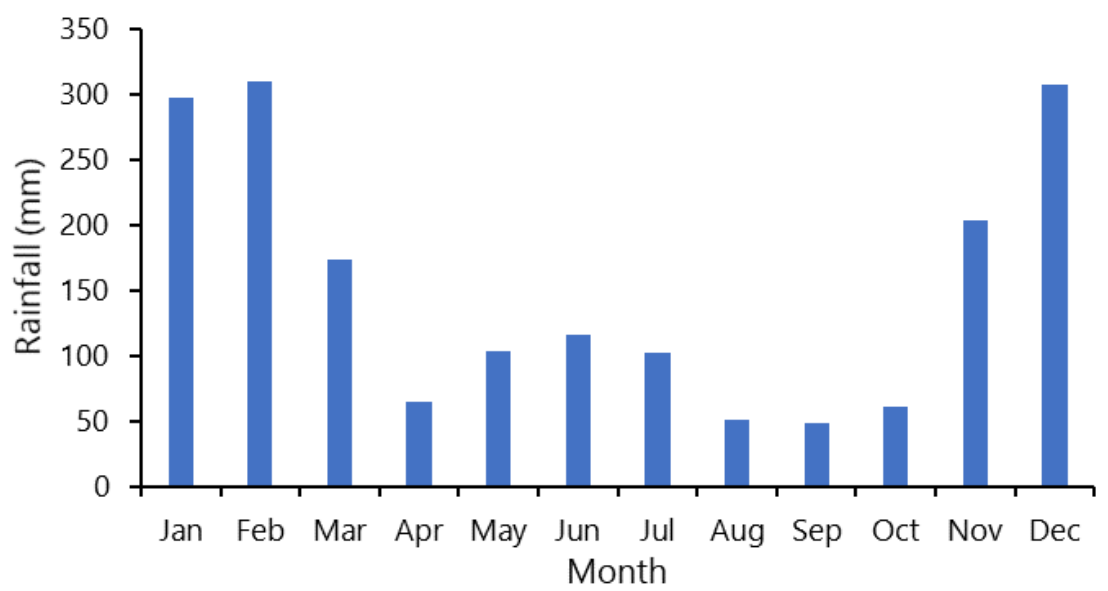

Figure 2. Average monthly rainfall $(\mathrm{mm})$ for period 2012-2018 in BPP Sukawati, Gianyar 
The frequency of irrigation water in chili-tobacco intercropping also had a significant effect on pest and disease outbreaks. The dominant outbreaks were observed in A4 treatment (six times irrigation water) except for tobacco leafhopper outbreaks. This result showed that more irrigation would increase the outbreaks. Tobacco leafhopper outbreaks predominantly occurred in $\mathrm{A} 1$ treatment (three times irrigation water) during the growing period of tobacco (Table 1). The six-times irrigation water in the growing period of chili-tobacco intercropping has caused the condition of land more humid. The results of soil moisture measurements supported this humidity as shown by high moisture content ( $100 \%)$, and a soil $\mathrm{pH}$ ranging from 6-6.7. The high moisture is suitable for fungi development that causes tobacco rotten root in addition to other pests.

The use of water in chili-tobacco intercropping showed significant differences in various treatments. Based on Romijn calculations, water use in the chilitobacco intercropping area varied from $7.05 \mathrm{~m}^{3} \mathrm{sec}^{-1}$ are $^{-1}$ (A1) to $13.18 \mathrm{~m}^{3} \mathrm{sec}^{-1}$ are $^{-1}$ (A4). The more frequency of irrigation, the area will require more water. For the optimal treatments i.e., the $\mathrm{A} 2$, the required water was $9.44 \mathrm{~m}^{3} \mathrm{sec}^{-1} \mathrm{are}^{-1}$, which produced the highest dry chopped tobacco leaves (11.5 ton ha-1). On the other hand, rice monoculture required more water about $45.17 \mathrm{~m}^{3} \mathrm{sec}^{-1} \mathrm{are}^{-1}$. This result revealed that water use of the intercropping system with chilitobacco was more efficient than that of rice by $79 \%$.

Table 1. Effect of irrigation frequency on the percentage of caterpillars, rotten roots, and tobacco leafhopper outbreaks

\begin{tabular}{lccc}
\hline Treatment & $\begin{array}{c}\text { Caterpillar } \\
\text { outbreaks (\%) }\end{array}$ & $\begin{array}{c}\text { Rotten root } \\
\text { outbreaks (\%) }\end{array}$ & $\begin{array}{c}\text { Tobacco leaf hopper } \\
\text { outbreaks (\%) }\end{array}$ \\
\hline A1 & $2.22 \pm 0.41 \mathrm{~b}$ & $11.43 \pm 3.77 \mathrm{c}$ & $24.87 \pm 5.65 \mathrm{a}$ \\
\hline $\mathrm{A} 2$ & $2.36 \pm 0.41 \mathrm{~b}$ & $12.86 \pm 4.48 \mathrm{c}$ & $18.05 \pm 4.43 \mathrm{~b}$ \\
\hline $\mathrm{A} 3$ & $2.32 \pm 0.42 \mathrm{~b}$ & $15.71 \pm 5.35 \mathrm{~b}$ & $22.94 \pm 3.71 \mathrm{a}$ \\
\hline $\mathrm{A} 4$ & $2.74 \pm 0.34 \mathrm{a}$ & $28.71 \pm 6.07 \mathrm{a}$ & $16.40 \pm 4.07 \mathrm{~b}$ \\
\hline $\begin{array}{l}\text { Diversity } \\
\text { coefficient (\%) }\end{array}$ & 10.67 & 8.89 & 19.94 \\
\hline BNT 5\% & 0.19 & & 3.05 \\
\hline
\end{tabular}

Note: Numbers followed by the same letter in the same column show no significant difference (5\% BNT test), where letter a indicates the highest value.

Intermittent irrigation is an alternative approach to maintained land on dry and wet alternately during the growing period. This type of irrigation was applied to rice plant from 10-day-old crops until the age of two weeks before harvest. A special treatment with an inundation of $3-5 \mathrm{~cm}$ was applied in a period of a week before and after flowering. Intermittent irrigation can reduce water losses without significantly reducing grained yield. A previous study suggested that intermittent irrigation was able to save water by $15 \%$ and does not reduce grain yield (Nugroho et al., 2018). Intermittent irrigation techniques accompanied by proper crop management can increase rice productivity at least $30 \%$, compared to the conventional one (Huda et al., 2013).

Table 2. Effect of irrigation frequency on the percentage of aphids, leaf curl viruses, and dry cut tobacco yield

\begin{tabular}{lccc}
\hline Treatment & Aphids attacks (\%) & $\begin{array}{c}\text { Tobacco leaf curl } \\
\text { viruses (\%) }\end{array}$ & $\begin{array}{c}\text { Dry chopped tobacco } \\
\text { leaves } \mathbf{( k g} / \mathbf{h a})\end{array}$ \\
\hline A1 & $11.91 \pm 2.77 \mathrm{~b}$ & $10.72 \pm 3.13 \mathrm{~b}$ & $11,181 \pm 18.89 \mathrm{~b}$ \\
\hline A2 & $12.04 \pm 1.75 \mathrm{~b}$ & $10.94 \pm 2.39 \mathrm{~b}$ & $11,500 \pm 4.91 \mathrm{a}$ \\
\hline A3 & $11.31 \pm 1.28 \mathrm{~b}$ & $11.59 \pm 0.85 \mathrm{~b}$ & $9,591 \pm 17.42 \mathrm{c}$ \\
\hline A4 & $13.65 \pm 0.98 \mathrm{a}$ & $14.18 \pm 0.62 \mathrm{a}$ & $8,364 \pm 29.40 \mathrm{~d}$ \\
\hline $\begin{array}{l}\text { Diversity } \\
\text { coefficient (\%) }\end{array}$ & 12.82 & 18.08 & 1.80 \\
\hline BNT 5\% & 1.16 & 1.59 & 13.59 \\
\hline
\end{tabular}

Note: Numbers followed by the same letter in the same column show no significant difference (5\% BNT test), where letter a indicates the highest value. 


\section{Farming Analysis of Tobacco in Subak Sange}

The total cost of tobacco cultivation was IDR 517.2 million for one life cycle. These costs were allocated for production facilities, labor, and other expenses, including ritual costs in the fields. With this production cost, the yield of dry chopped tobacco leaves was 11.5 tons ( IDR 920 million). The total profit earned by farmers was about IDR 402.8 million. Therefore, the revenue cost ratio (RCR) was 1.78 , which means that the farming of chili-tobacco intercropping was feasible (Table 3).

Table 3. Farming analysis of tobacco (per hectare) at Subak Sange farmland

\begin{tabular}{lrrrc}
\hline Production Facilities & Vol & Unit & $\begin{array}{c}\text { Cost } \\
\text { (Thousand IDR) }\end{array}$ & $\begin{array}{c}\text { Amount } \\
\text { (Million IDR) }\end{array}$ \\
\hline Urea & 7.5 & ton & 2 & 5 \\
\hline SP36 & 1 & ton & 2.2 & 2.2 \\
\hline Fee & & & & \\
\hline Tractor & 100 & are & 20 & 20 \\
\hline Chaff-cutter & 100 & are & 10 & 10 \\
\hline Ridging & 200 & day & 100 & 20 \\
\hline Seedbed & 100 & day & 100 & 10 \\
\hline Planting & 150 & day & 100 & 15 \\
\hline Irrigation and weeding & 600 & day & 100 & 60 \\
\hline Banking & 100 & day & 100 & 10 \\
\hline Pruning & 400 & day & 100 & 40 \\
\hline Harvesting & 800 & day & 100 & 80 \\
\hline Chopping and drying & 700 & day & 100 & 70 \\
\hline Packing & 150 & day & 100 & 15 \\
\hline Ground rent & & & 100,000 & 100 \\
\hline Others & & & 50,000 & 50 \\
\hline Total cost & & & & $\mathbf{5 1 7 . 2}$ \\
\hline Production (kg) & $\mathbf{1 1 . 5}$ & ton & $\mathbf{8 0}$ & $\mathbf{9 2 0}$ \\
\hline Profit & & & & $\mathbf{4 0 2 . 8}$ \\
\hline RCR & & & & 1.78 \\
\hline & & & & \\
\hline
\end{tabular}

\section{CONCLUSION}

Local wisdom of Subak Sange was an ancestral heritage that harmonizes three aspects, namely the socio-agrarian-religious aspects. In order to improve the water use efficiency in the conventional Subak system, farmers introduced the chili-tobacco intercropping, which was proven to increase water use efficiency by $79 \%$ compared to the monoculture rice cultivation. The findings revealed that more irrigation would increase pest and disease outbreaks on chilitobacco plants. Further, the optimal frequency of irrigation water was four times during the planting period, which resulted in 11.5 tons of dry chopped tobacco per ha. Based on the revenue cost ratio, the chili-tobacco intercropping with four times irrigation was feasible. The findings indicate that management of irrigation water in Subak Sange are promising to support food sustainability in the region.

\section{ACKNOWLEDGEMENT}

The author would like to thank the Agricultural Research and Development Agency, Ministry of Agriculture, on activities and budgets with letter numbers: B-45/Kpts/OT 050/H.12.16/01/2019 about Agricultural Technology Innovation Support for Increasing the Plant Index. Thanks to the field officers, irrigation system administrator, and farmer groups of Subak Sange-Gianyar, for the land used as a research site. The author gives thanks to friends who cannot be mentioned one by one for their kind help, hopefully always bestowed health in their life. 


\section{REFERENCES}

Abdolahipour, M., Kamgar-Haghighi, A.A., Sepaskhah, A.R., 2018. Time and amount of supplemental irrigation at different distances from tree trunks influence on soil water distribution, evaporation and evapotranspiration in rainfed fig orchards. Agricultural Water Management 203, 322-332. https://doi.org/10.1016/j.agwat.2018.03.030

Andayani, R., Djohan, B., Arlingga, K.A., 2017. Penanganan Banjir Dengan Kolam Retensi (Retarding Basin) di Kelurahan Gandus Kota Palembang. Jurnal Teknik Sipil 7, 27-33.

Ashofteh Parisa-Sadat, Bozorg-Haddad Omid, Loáiciga Hugo A., 2017. Impacts of Climate Change on the Conflict between Water Resources and Agricultural Water Use. Journal of Irrigation and Drainage Engineering 143, 02516002. https://doi.org/10.1061/(ASCE)IR.19434774.0001143

Asnidar, A., Asrida, A., 2017. Analisis Kelayakan Usaha Home Industry Kerupuk Opak di Desa Paloh Meunasah Dayah Kecamatan Muara Satu Kabupaten Aceh Utara. Jurnal Sains Pertanian 1.

Badan Litbang Pertanian, 2007. Pengelolaan Tanaman Terpadu (PTT) Padi Sawah Irigasi, Petunjuk Teknis Lapang. Badan Litbang Pertania, Departemen Pertanian.

Boulay, A.-M., Bare, J., Benini, L., Berger, M., Lathuillière, M.J., Manzardo, A., Margni, M., Motoshita, M., Núñez, M., Pastor, A.V., Ridoutt, B., Oki, T., Worbe, S., Pfister, S., 2018. The WULCA consensus characterization model for water scarcity footprints: assessing impacts of water consumption based on available water remaining (AWARE). The International Journal of Life Cycle Assessment 23, 368-378. https://doi.org/10.1007/s11367-017-1333-8

Flörke, M., Schneider, C., McDonald, R.I., 2018. Water competition between cities and agriculture driven by climate change and urban growth. Nature Sustainability 1, 51-58. https://doi.org/10.1038/s41893-017-0006-8

Gomez, K.A., Gomez, A.A., 1995. Prosedur statistik untuk penelitian pertanian. Edisi ke 2 .

Huda, M.N., Harisuseno, D., Priyantoro, D., 2013. Kajian Sistem Pemberian Air Irigasi sebagai Dasar Penyusunan Jadwal Rotasi pada Daerah Irigasi Tumpang Kabupaten Malang. Jurnal Teknik Pengairan 3, 221-229.

Ilangumaran, G., Smith, D.L., 2017. Plant Growth Promoting Rhizobacteria in Amelioration of
Salinity Stress: A Systems Biology Perspective. Frontiers in Plant Science 8, 1768. https://doi.org/10.3389/fpls.2017.01768

Jansing, M.S., Mahichi, F., Dasanayake, R., 2020. Sustainable Irrigation Management in Paddy Rice Agriculture: A Comparative Case Study of Karangasem Indonesia and Kunisaki Japan. Sustainability $12, \quad 1180$ https://doi.org/10.3390/su12031180

Kang, S., Hao, X., Du, T., Tong, L., Su, X., Lu, H., Li, X., Huo, Z., Li, S., Ding, R., 2017. Improving agricultural water productivity to ensure food security in China under changing environment: From research to practice. Agricultural Water Management 179, 5-17. https://doi.org/10.1016/j.agwat.2016.05.007

Lambers, H., Oliveira, R.S., 2019. Plant water relations, in: Plant Physiological Ecology. Springer, pp. 187-263.

Luo, B., Maqsood, I., Yin, Y., Huang, G., Cohen, S., 2015. Adaption to climate change through water trading under uncertainty-An inexact twostage nonlinear programming approach. Journal of Environmental Informatics 2, 58-68.

Norken, I.N., Suputra, I.K., Arsana, I., Ngurah, I., 2017. Institutional and Regulatory Roles in Maintaining Sustainability of Subak as a World Cultural Heritage in Bali. Asian Agri-History 21, 245-254.

Nugroho, B.D.A., Toriyama, K., Kobayashi, K., Arif, C., Yokoyama, S., Mizoguchi, M., 2018. Effect of intermittent irrigation following the system of rice intensification (SRI) on rice yield in a farmer's paddy fields in Indonesia. Paddy and Water Environment 16, 715-723. https://doi.org/10.1007/s10333-018-0663-x

Parent, B., Shahinnia, F., Maphosa, L., Berger, B., Rabie, H., Chalmers, K., Kovalchuk, A., Langridge, P., Fleury, D., 2015. Combining field performance with controlled environment plant imaging to identify the genetic control of growth and transpiration underlying yield response to water-deficit stress in wheat. Journal of Experimental Botany 66, 5481-5492. https://doi.org/10.1093/jxb/erv320

Petersen-Perlman, J.D., Veilleux, J.C., Wolf, A.T., 2017. International water conflict and cooperation: challenges and opportunities. Water International 42, 105-120.

Putra, P.A., Yuliando, H., 2015. Soilless culture system to support water use efficiency and product quality: a review. Agriculture and Agricultural Science Procedia 3, 283-288. 
Quist-Jensen, C.A., Macedonio, F., Drioli, E., 2015. Membrane technology for water production in agriculture: Desalination and wastewater reuse. Desalination 364, 17-32. https://doi.org/10.1016/j.desal.2015.03.001

Seidel, S.J., Werisch, S., Schütze, N., Laber, H., 2017. Impact of irrigation on plant growth and development of white cabbage. Agricultural Water Management 187, 99-111. https://doi.org/10.1016/j.agwat.2017.03.011

Sulaiman, A.A., Agus, F., Noor, M., Dariah, A., Irawan, B., Surmaini, E., 2018. Jurus Jitu Menyikapi Iklim Ekstrem El Nino dan La Nina untuk Pemantapan Ketahanan Pangan. IAARD Press, Badan Penelitian dan Pengembangan Pertanian.

Tarigan, H., Dharmawan, A.H., Tjondronegoro, S., Suradisastra, K., 2016. Persaingan Akses Sumber Daya Air di Yeh Ho, Tabanan, Bali. Jurnal Agro Ekonomi 31, 143-159.

Wijayanti, P.U., Windia, W., Darmawan, D.P., Widhianthini, W., 2020. Sustainable development model of subak in Denpasar City. ijls 4. https://doi.org/10.29332/ijls.v4n1.418
Wu, M., Schurgers, G., Rummukainen, M., Smith, B., Samuelsson, P., Jansson, C., Siltberg, J., May, W., 2016. Vegetation-climate feedbacks modulate rainfall patterns in Africa under future climate change. Earth System Dynamics 7, 627-647. https://doi.org/10.5194/esd-7-627-2016

Wulandari, D.R., Purwito, A., Susanto, S., Husni, A., Ermayanti, T.M., 2018. Protoplast Fusion between Indonesian Citrus maxima (Burm.) Merr. and Citrus reticulata L.: A Preliminary Report. AGRIVITA, Journal of Agricultural Science 40, 233-241.

Yekti, M.I., Schultz, B., Norken, I.N., Gany, A.H.A., Hayde, L., 2017. Learning from Experiences of Ancient Subak Schemes for Participatory Irrigation System Management in Bali. Irrigation and Drainage 66, 567-576. https://doi.org/10.1002/ird.2122

Yusara, A., Handoko, H., Budianto, B., 2019. Water Demand Analysis of Sugarcane Based on Crop Simulation Model (Case Study: Kediri Regency, East Java). Agromet 33, 30-40. https://doi.org/10.29244/j.agromet.33.1.30-40 